n.tronos

glyndwhr

Glyndŵr University

Glyndŵr University Research Online

Centre for Solar Energy Research

Materials Science

$3-1-2012$

\title{
MOCVD of Cd(1-x)Zn(x)S/CdTe PV cells using an ultra-thin absorber layer
}

Andrew J. Clayton

Glyndwr University, a.clayton@glyndwr.ac.uk

Stuart J. Irvine

Glyndwr University, s.irvine@glyndwr.ac.uk

EW. Jones

Giray Kartopu

Glyndwr University, g.kartopu@glyndwr.ac.uk

Vincent Barrioz

Glyndwr University, v.barrioz@glyndwr.ac.uk

See next page for additional authors

Follow this and additional works at: http://epubs.glyndwr.ac.uk/sol

Part of the Analytical Chemistry Commons, Atomic, Molecular and Optical Physics Commons, Energy Systems Commons, Engineering Physics Commons, Inorganic Chemistry Commons, Manufacturing Commons, Materials Chemistry Commons, Other Chemical Engineering Commons, Other Physics Commons, Physical Chemistry Commons, Semiconductor and Optical Materials Commons, $\underline{\text { Structural Materials Commons, and the Thermodynamics Commons }}$

\section{Recommended Citation}

Clayton, A.J., Irvine, S.J.C., Jones, E.W. Kartopu, G., Barrioz, V., and Brooks, W.S.M. (2012) “MOCVD of Cd(1-x)Zn(x)S/CdTe PV cells using an ultra-thin absorber layer". Solar Energy Materials \& Solar Cells, Volume 101 pp. 68-72.

This Article is brought to you for free and open access by the Materials Science at Glyndŵr University Research Online. It has been accepted for inclusion in Centre for Solar Energy Research by an authorized administrator of Glyndŵr University Research Online. For more information, please contact d.jepson@glyndwr.ac.uk. 


\title{
MOCVD of Cd(1-x)Zn(x)S/CdTe PV cells using an ultra-thin absorber
}

layer

\begin{abstract}
Ultra-thin $\mathrm{Cd}(1-x) \mathrm{Zn}(\times) \mathrm{S} / \mathrm{CdTe}$ devices were produced by atmospheric pressure metal organic chemical vapour deposition (AP-MOCVD) with varying CdTe absorber thicknesses ranging from 1.0 to $0.2 \mathrm{~mm}$ and compared to baseline cells with total CdTe thickness of $2.25 \mu$. The ultra-thin CdTe layers $(\leq 1 \mu \mathrm{m})$ were intentionally doped with As to induce p-type conductivity in the absorber. Cell performance reduced with CdTe thickness, with the magnitude of photo-current generation loss becoming more significant for the very thin CdTe layers. The decline in cell performance was lower than the optically limited performance relating to a decrease in shunt resistance, Rsh, especially for the thinnest cells due to areas of incomplete CdTe coverage and large presence of pin-holes leading to micro-shorts. Incorporation of $\mathrm{Zn}$ into the $\mathrm{CdS}$ window layer improved cell performance for all devices except when $0.2 \mu \mathrm{m}$ thick CdTe was used. This improvement was markedly in the blue region owing to enhanced optical transparency of the window layer. External quantum efficiency (EQE) measurements showed a red-shift of the window layer absorption edge due to leaching out of $\mathrm{Zn}$ during the $\mathrm{CdCl}_{2}$ treatment. Reduction of the $\mathrm{CdCl}_{2}$ deposition time was demonstrated to recover the blue response of the ultra-thin cells.
\end{abstract}

\section{Keywords}

thin film photovoltaics, CdTe, MOCVD

\section{Disciplines}

Analytical Chemistry | Atomic, Molecular and Optical Physics | Chemical Engineering | Chemistry| Energy Systems | Engineering Physics | Inorganic Chemistry | Manufacturing | Materials Chemistry | Materials Science and Engineering | Mechanical Engineering | Other Chemical Engineering | Other Physics | Physical Chemistry | Physics | Semiconductor and Optical Materials | Structural Materials | Thermodynamics

\section{Comments}

Copyright (C) 2012 Elsevier. All rights reserved. NOTICE: this is the author's version of a work that was accepted for publication in Solar Energy Materials and Solar Cells. Changes resulting from the publishing process, such as peer review, editing, corrections, structural formatting, and other quality control mechanisms may not be reflected in this document. Changes may have been made to this work since it was submitted for publication. A definitive version was subsequently published in Clayton, A.J., Irvine, S.J.C., Jones, E.W. Kartopu, G., Barrioz, V., and Brooks, W.S.M. (2012) "MOCVD of Cd(1-x)Zn(x)S/CdTe PV cells using an ultrathin absorber layer". Solar Energy Materials \& Solar Cells, Volume 101 pp. 68-72. and is located at http://dx.doi.org/10.1016/j.solmat.2012.02.018

\section{Authors}

Andrew J. Clayton, Stuart J. Irvine, E W. Jones, Giray Kartopu, Vincent Barrioz, and Will S. Brooks 


\title{
MOCVD of $\mathrm{Cd}_{(1-\mathrm{x})} \mathrm{Zn}_{(\mathrm{x})} \mathrm{S} / \mathrm{CdTe} \mathrm{PV}$ cells using an ultra-thin absorber layer
}

\author{
A. J. Clayton, ${ }^{*}$ S.J.C. Irvine, E.W. Jones, G. Kartopu, V. Barrioz, W.S.M. Brooks
}

Centre for Solar Energy Research, Glyndŵr University, OpTIC Glyndŵr, St. Asaph Business Park, Denbighshire, UK. Fax: 441745 535101; Tel: 441745 535213; * a.clayton@glyndwr.ac.uk.

Ultra-thin $\mathrm{Cd}_{(1-\mathrm{x})} \mathrm{Zn}_{(\mathrm{x})} \mathrm{S} / \mathrm{CdTe}$ devices were produced by atmospheric pressure metal organic chemical vapour deposition (AP-MOCVD) with varying CdTe absorber thicknesses ranging from 1.0 to $0.2 \mu \mathrm{m}$ and compared to baseline cells with total CdTe thickness of $2.25 \mu \mathrm{m}$. The ultra-thin CdTe layers $(\leq 1 \mu \mathrm{m})$ were intentionally doped with As to induce p-type conductivity in the absorber. Cell performance reduced with CdTe thickness, with the magnitude of photo-current generation loss becoming more significant for the very thin CdTe layers. The decline in cell performance was lower than the optically limited performance relating to a decrease in shunt resistance, $R_{s h}$, especially for the thinnest cells due to areas of incomplete CdTe coverage and large presence of pin-holes leading to micro-shorts. Incorporation of $\mathrm{Zn}$ into the $\mathrm{CdS}$ window layer improved cell performance for all devices except when $0.2 \mu \mathrm{m}$ thick CdTe was used. This improvement was markedly in the blue region owing to enhanced optical transparency of the window layer. External quantum efficiency (EQE) measurements showed a red-shift of the window layer absorption edge due to leaching out of $\mathrm{Zn}$ during the $\mathrm{CdCl}_{2}$ treatment. Reduction of the $\mathrm{CdCl}_{2}$ deposition time was demonstrated to recover the blue response of the ultra-thin cells.

Keywords: thin film photovoltaics; CdTe; MOCVD.

\section{Introduction}

Reduction of the CdTe absorber layer thickness in thin film CdS/CdTe photovoltaic (PV) solar cells is an attractive prospect due to limited availability and the rising price of Te with regards to very high volume PV module manufacture in the future. Another advantage is that overall material consumption will decrease along with module production costs. The challenge in using ultra-thin absorber layers is to avoid pin-hole formation so as to maintain the photo-current generation and overall cell performance to the optical absorption limits. A theoretical study by Amin et al. [1] showed that the majority of carrier generation in the PV cell occurred close to the CdS/CdTe junction and reduced by two orders of magnitude within the first $1 \mu \mathrm{m}$ of the CdTe absorber layer. Depending on its size, a pin-hole running from the back contact through the $p-n$ junction and window layer to the front contact can either diminish or even destroy the cell performance. Hence, CdTe thicknesses from 2 - $10 \mu \mathrm{m}$ are typically adopted. To further reduce the CdTe thickness without compromising the (ultra) thin film quality, a controllable process capable of producing uniform layers, such as metal organic chemical vapour deposition (MOCVD) [2 - 8], must be used.

Irvine et al. [2] investigated the potential towards reducing absorber layer thicknesses in $\mathrm{CdS} / \mathrm{CdTe}$ solar cells concluding that comprehensive substrate cleaning was required to minimise pin-hole formation. A following study conducted by Jones et al. [3] on solar cell performance of ultra-thin CdS/CdTe PV cells, employing CdTe absorber thicknesses ranging from $1 \mu \mathrm{m}$ down to $0.2 \mu \mathrm{m}$, showed that the reduction of CdTe thickness had little effect on the series resistance. This indicated that the barrier at the back contact was unaffected by the close proximity of the p-n junction. Nevertheless, cell efficiency was observed to decrease as the CdTe thickness reduced, characterised with low open circuit voltage $\left(\mathrm{V}_{\mathrm{oc}}\right)$ and low fill factor $(\mathrm{FF})$ due to increased shunting (low shunt resistance). Another factor could have been recombination at the back contact, as identified by Plotnikov et al. [9] using current density-voltage $J-V$ vs. temperature $(J-V-T)$ measurements, who also found bifacial illumination to be majorly significant for ultra-thin CdTe PV cells. Over-treatment of ultra-thin $\mathrm{CdS} / \mathrm{CdTe}$ cells during $\mathrm{CdCl}_{2}$ processing and diffusion of $\mathrm{Cu}$ for $\mathrm{Cu} / \mathrm{Au}$ back contact formation was also observed by Gupta et al. [10] to be detrimental to cell performance, due to outdiffusion of $\mathrm{Cu}$ from the back contact into the region of the junction. It was found that $\mathrm{CdCl}_{2}$ treatment could be reduced to a lower arbitrary level whilst the $\mathrm{Cu}$ diffusion time was the most critical parameter having the most influence on the end cell performance. 
In the current study we investigated in detail the influence of processing conditions on the performance of ultra-thin MOCVD $\mathrm{Cd}_{(1-x)} \mathrm{Zn}_{(\mathrm{x})} \mathrm{S} / \mathrm{CdTe}$ solar cells. Use of $\mathrm{Cd}_{(1-\mathrm{x})} \mathrm{Zn}_{(\mathrm{x})} \mathrm{S}$ was first demonstrated by Chu et al. [4] with reported increase in window layer band gap $\left(E_{\mathrm{g}}\right)$ from $2.4 \mathrm{eV}$ to $\sim 2.8 \mathrm{eV}$. However, the resulting solar cells only gave reasonable PV performance when an intermediate $\mathrm{Cd}_{(1-x)} Z \mathrm{n}_{(\mathrm{x})}$ Te layer was incorporated between the $\mathrm{Cd}_{(1-x)} Z \mathrm{n}_{(\mathrm{x})} \mathrm{S} / \mathrm{CdTe}$ interface. Irvine et al. [5] were able to show the benefit of the window layer (reporting $E_{g} \sim 2.7 \mathrm{eV}$ ) for $\mathrm{Cd}_{(1-\mathrm{x})} Z \mathrm{n}_{(\mathrm{x})} \mathrm{S} / \mathrm{CdTe}$ cell structures, using a baseline absorber thickness of $2.25 \mu \mathrm{m}$. The inclusion of a $\mathrm{Cd}_{(1-\mathrm{x})} \mathrm{Zn}(\mathrm{n}) \mathrm{S}$ window layer by Jones et al. [3] adopting the method of Irvine et al. [5] resulted in improved cell performance for a $1 \mu \mathrm{m}$ thick CdTe device. Herein, a systematic comparison is made between MOCVD ultra-thin devices utilising CdS and $\left.C d_{(1-x)}\right) n_{(x)} S$ window layers, with characterisation of cell performance as a function of CdTe absorber thickness.

\section{Experimental}

\subsection{MOCVD growth process}

$\mathrm{Cd}_{(1-x)} \mathrm{Zn}_{(\mathrm{x})} \mathrm{S} / \mathrm{CdTe}$ solar cells were deposited onto commercial ITO coated aluminosilicate glass substrates using MOCVD at atmospheric pressure (AP-MOCVD). The substrates for the ultra-thin devices were $2.5 \times 5.0 \mathrm{~cm}^{2}$ with ITO sheet resistance $5-15 \Omega / \square$ supplied by Delta-Technologies Ltd. and were static within the reactor chamber. The deposition used a horizontal configuration and purified $\mathrm{H}_{2}$ as carrier gas with growth temperatures in the range $200-420^{\circ} \mathrm{C}$. The $\mathrm{Cd}, \mathrm{Zn}, \mathrm{S}, \mathrm{Te}, \mathrm{As}$ and $\mathrm{Cl}$ precursors were dimethylcadmium, diethylzinc, ditertiarybutylsulphide, diisopropyltelluride, trisdimethylaminoarsine and tertiarybutylchloride, respectively. An in situ triple wavelength laser reflectometer manufactured by ORS Ltd. was used to monitor the growing layer thickness and deposition rate for all window and absorber layers.

The baseline process utilises an As concentration of $2 \times 10^{18}$ atoms $/ \mathrm{cm}^{3}$ for the bulk CdTe absorber layer, with increased As-doping at $1 \times 10^{19}$ atoms $/ \mathrm{cm}^{3}$ for the back contact layer (BCL) giving the cells a npp ${ }^{+}$type structure [6] improving the ohmic characteristics of the Au back contact, which may be due to a reduction of carrier recombination in this region [11]. $\mathrm{CdCl}_{2}$ treatment was carried out in situ after growth of the CdTe layers [7], which comprised of a $\mathrm{CdCl}_{2}$ deposition followed by an anneal under $\mathrm{H}_{2}$ at $420^{\circ} \mathrm{C}$. Therefore the MOCVD process for producing the thin film solar cells was continuous, using a single growth chamber.

A constant window layer thickness of $0.24 \mu \mathrm{m}$ was used for all baseline and ultra-thin devices. This thickness has been shown [12, 13] by triple wavelength laser beam induced current (LBIC) measurements to give optimum photo-current generation in $\mathrm{CdTe}$. Thinner window layers resulted in a more variable nucleation of MOCVD $\mathrm{Cd}_{(1-x)} \mathrm{Zn}_{(\mathrm{x})} \mathrm{S}$ and were more susceptible to formation of localised ITO/CdTe junctions, with inferior characteristics to $\mathrm{Cd}_{(1-x)} \mathrm{Zn} \mathrm{n}_{(\mathrm{x})} \mathrm{S} / \mathrm{CdTe}$ junctions.

The baseline device was $5.0 \times 7.5 \mathrm{~cm}^{2}$ with sixteen Au contacts each of $0.25 \mathrm{~cm}^{2}$ in area, whereas the devices with CdTe thickness 0.5 and $1 \mu \mathrm{m}$ were grown over two $2.5 \times 5.0 \mathrm{~cm}^{2}$ substrates placed side-by-side with eight Au contacts on each also having $0.25 \mathrm{~cm}^{2}$ in area for direct comparison to baseline cell results. Mean results have been used from $J-V$ measurements taken from the sixteen cells. Only one $2.5 \times 5.0 \mathrm{~cm}^{2}$ substrate was used for the thinnest device with $0.2 \mu \mathrm{m}$ thick CdTe due to increased and non-negligible variation in CdTe thickness (with distance from the precursor inlet) over two substrates. Mean $J-V$ results for the thinnest device were therefore taken from eight cells.

\subsection{Characterisation and cell details}

Combined thickness of the window and treated absorber layers was measured near each cell for the series of devices using a Veeco Dektak stylus 150 profilometer after exposing the indium tin oxide (ITO) front contact to verify thickness measured by the in situ laser reflectometer. The $\mathrm{J}-\mathrm{V}$ measurements were carried out with only front (junction-side) illumination under AM1.5 using an Abet Technologies Ltd. solar simulator with light power density output equal to $100 \mathrm{~mW} / \mathrm{cm}^{2}$ measured with a broadband thermopile power meter calibrated using a mono-FZ-Si reference cell. External quantum efficiency (EQE) measurements were carried out using a Bentham spectral response spectrometer under unbiased conditions over the spectral range $0.3-1 \mu \mathrm{m}$. Secondary ion mass spectroscopy (SIMS) was carried out at Loughborough Surface Analysis Ltd. using a Cameca ims $4 \mathrm{f}$ instrument with $\mathrm{O}_{2}{ }^{+}$as the primary ion using a current of $500 \mathrm{nA}$ and energy of $10 \mathrm{keV}$ for positive secondary ion detection. The raster area over the samples was $200 \mu \mathrm{m}^{2}$ with an analysed area of $60 \mu \mathrm{m}^{2}$. 
A previous investigation [3] reported that the BCL was not necessary for a $\mathrm{CdS} / \mathrm{CdTe}$ cell with absorber thickness of $1 \mu \mathrm{m}$ to overcome rollover behaviour in $J-V$ measurements, enabling use of a simplified $\mathrm{np}$ type cell structure. Therefore, cell performance of a series of ultra-thin $\mathrm{Cd}_{(1-}$ ${ }_{x)} \mathrm{Zn}_{(\mathrm{x}) \mathrm{S}} \mathrm{S} / \mathrm{CdTe}$ devices with $\mathrm{np}$ type structure having CdTe thickness ranging from 0.2 to $1 \mu \mathrm{m}$ has been investigated in comparison to equivalent $\mathrm{CdS} / \mathrm{CdTe}$ devices. For the thin cell structures with CdTe thickness $\leq 1 \mu \mathrm{m}$ the $\mathrm{CdCl}_{2}$ deposition time was reduced by half relative to the baseline process which used the npp ${ }^{+}$cell structure with total CdTe absorber thickness of $2.25 \mu \mathrm{m}$.

\section{Results \& Discussion}

\section{1. $J-V$ results}

Mean results for PV performance of the ultra-thin cells displayed in Table 1 show an evident deterioration in all $J-V$ parameters as the CdTe thickness was reduced. This is due, in part, to reducing photo-current generation as the absorber layer thickness became much smaller than the photon absorption length, which was the case for cells with either a CdS or $\mathrm{Cd}_{(1-x)} Z_{(\mathrm{x})} S$ window layer. However, the wider band gap $\mathrm{Cd}_{(1-x)} Z \mathrm{n}_{(\mathrm{x})} S$ window layer increased short current density $\left(\mathrm{J}_{\mathrm{sc}}\right)$ for all cell thicknesses as expected from the increased photo-generation from the blue region.

Table 1: Mean J-V results with standard deviation for CdS/CdTe and $C d_{(1-x)} Z n_{(x)} S / C d T e$ cells with CdTe absorber thicknesses ranging from 2.25 to $0.2 \mu \mathrm{m}$.

\begin{tabular}{cccccc}
\hline Window & CdTe $(\mu \mathrm{m})$ & Eff $(\%)$ & $\mathrm{J}_{\mathbf{s c}}\left(\mathrm{mA} / \mathrm{cm}^{2}\right)$ & $\mathrm{V}_{\text {oc }}(\mathrm{mV})$ & $\mathbf{F F}(\%)$ \\
\hline CdS & $2.25+/-0.15$ & $9.0+/-0.7$ & $21.4+/-0.8$ & $656+/-82$ & $64.1+/-3.7$ \\
& $1.0+/-0.10$ & $6.8+/-1.2$ & $20.0+/-0.4$ & $564+/-54$ & $59.0+/-6.4$ \\
& $0.5+/-0.07$ & $5.8+/-1.5$ & $18.0+/-1.1$ & $548+/-54$ & $57.3+/-10.3$ \\
& $0.2+/-0.04$ & $2.3+/-0.8$ & $11.9+/-0.3$ & $445+/-12$ & $43.0+/-9.3$ \\
\hline CdZnS & $2.25+/-0.15$ & $10.9+/-0.5$ & $23.3+/-0.3$ & $665+/-26$ & $70.4+/-1.3$ \\
& $1.0+/-0.13$ & $8.9+/-0.2$ & $21.5+/-0.4$ & $622+/-8$ & $66.1+/-1.0$ \\
& $0.5+/-0.07$ & $6.9+/-0.5$ & $19.4+/-0.5$ & $579+/-10$ & $61.5+/-3.5$ \\
& $0.2+/-0.03$ & $2.2+/-1.2$ & $15.6+/-0.8$ & $370+/-100$ & $35.1+/-9.3$ \\
\hline
\end{tabular}

The series resistance $\left(R_{s}\right)$ and shunt resistance $\left(R_{s h}\right)$ calculated as an average from the $J-V$ curves for different CdS/CdTe and $\mathrm{Cd}_{(1-\mathrm{x})} \mathrm{Zn}_{(\mathrm{x})} \mathrm{S} / \mathrm{CdTe}$ cell thicknesses are shown in Table 2. It can be seen that $R_{s}$ is not affected, in agreement with Ref. 3, by the shorter distance between the back contact and p-n junction with reduced absorber thickness.

Table 2: Mean series $\left(R_{s}\right)$ and shunt resistance $\left(R_{s h}\right)$ values with standard deviation for cells with CdTe absorber thicknesses ranging from 2.25 to $0.2 \mu \mathrm{m}$ calculated from J-V curves for CdS/CdTe and $C d_{(1-x)} Z n_{(x)} S / C d T e P V$ cells.

\begin{tabular}{cccc}
\hline Window & $\mathbf{C d T e}(\mu \mathrm{m})$ & $\mathbf{R}_{\mathbf{s}}\left(\Omega \cdot \mathbf{c m}^{2}\right)$ & $\mathbf{R}_{\mathbf{s h}}\left(\Omega \cdot \mathbf{c m}^{2}\right)$ \\
\hline CdS & $2.25+/-0.15$ & $3.8+/-0.9$ & $1684+/-968$ \\
& $1.0+/-0.10$ & $3.7+/-0.7$ & $684+/-229$ \\
& $0.5+/-0.07$ & $2.1+/-0.4$ & $389+/-207$ \\
& $0.2+/-0.04$ & $2.1+/-0.1$ & $109+/-62$ \\
\hline CdZnS & $2.25+/-0.15$ & $2.6+/-0.1$ & $1573+/-458$ \\
& $1.0+/-0.13$ & $2.1+/-0.2$ & $1087+/-122$ \\
& $0.5+/-0.07$ & $2.0+/-0.4$ & $453+/-116$ \\
& $0.2+/-0.03$ & $2.1+/-0.2$ & $56+/-43$ \\
\hline
\end{tabular}

With the exception of the thinnest cell structure, all $J-V$ parameters were increased for the $C d_{(1-}$ ${ }_{x)} Z n_{(x)} S / C d T e$ cells relative to the CdS/CdTe cells. J-V parameters for the $\mathrm{Cd}_{(1-x)} \mathrm{Zn}_{(\mathrm{x})} \mathrm{S} / \mathrm{CdTe}$ cells with $1 \mu \mathrm{m}$ thick CdTe are comparable to the CdS/CdTe cells with baseline CdTe thickness of $2.25 \mu \mathrm{m}$. 
At each absorber thickness, for the two cell structures, there is a direct correlation between $V_{o c}$ and $F F$, where both decrease for thinner absorbers. The $\mathrm{Cd}_{(1-x)} \mathrm{Zn}_{(\mathrm{x})} \mathrm{S} / \mathrm{CdTe}$ cell structure had higher $\mathrm{V}_{\mathrm{oc}}$ and FF for the majority of absorber thicknesses, with the exception of the thinnest device where values dropped relative to the CdS/CdTe cell structure. This reflects the poor overall performance of the thinnest devices, with little difference between the $\mathrm{Cd}_{(1-\mathrm{x})} \mathrm{Zn}_{(\mathrm{x})} \mathrm{S} / \mathrm{CdTe}$ and $\mathrm{CdS} / \mathrm{CdTe}$ counterpart, despite enhancement in $\mathrm{J}_{\mathrm{sc}}$ for the former cell structure.

The cause for the deterioration in the $J-V$ parameters could be explained by the presence of microshorts $[8,12,13]$ in the cells due to incomplete coverage of the CdTe, becoming more prominent as absorber thickness is reduced and being most severe at $0.2 \mu \mathrm{m}$. The presence of micro-shorts is supported by the significant fall in $R_{\text {sh }}$ for the ultra-thin cells with CdTe absorber $<1 \mu \mathrm{m}$. For the baseline CdS/CdTe cells, the larger $R_{S}$ may be contributing to the reduced $F F$ relative to the $C_{(1-}$ ${ }_{x)} \mathrm{Zn}_{(\mathrm{x})} \mathrm{S} / \mathrm{CdTe}$ cells, where $R_{\mathrm{sh}}$ for both cell structures is $>1500 \Omega \cdot \mathrm{cm}^{2}$. Table 1 shows that whilst the $\mathrm{Cd}_{(1-\mathrm{x})} \mathrm{Zn}(\mathrm{x}) \mathrm{S} / \mathrm{CdTe}$ cells with $0.2 \mu \mathrm{m}$ thick CdTe seem to have suffered more with non-uniformities across the device, with a resulting fall in $\mathrm{V}_{\mathrm{oc}}$ and $\mathrm{FF}$, there is a dramatic drop in $\mathrm{J}_{\mathrm{sc}}$ for the equivalent $\mathrm{CdS} / \mathrm{CdTe}$ cells. The $\mathrm{J}_{\mathrm{sc}}$ is still relatively high at $15.6 \mathrm{~mA} / \mathrm{cm}^{2}$ for the $\mathrm{Cd}_{(1-x)} \mathrm{Zn}_{(\mathrm{x})} \mathrm{S} / \mathrm{CdTe}$ cells, even though the absorber is reduced in thickness tenfold from the baseline device. Therefore, a small gain in photo-current can still be observed even for these ultra-thin cells with the use of the wider band gap $C d_{(1-x)} Z n_{(x)} S$ window layer. This clearly illustrates the benefit of the improved blue response and is an exciting result demonstrating the potential for using less CdTe in PV cells.

Fig. 1 shows dark $J-V$ curves for the $\mathrm{Cd}_{(1-x)} Z \mathrm{n}_{(\mathrm{x})} \mathrm{S} / \mathrm{CdTe}$ structures, where the cells with absorber thicknesses down to $0.5 \mu \mathrm{m}$ show good rectification. The cell with $0.2 \mu \mathrm{m}$ thick $\mathrm{CdTe}$, however, is showing poorer diode characteristics with a strong shunted behaviour. This further supports the presence of micro-shorting correlating with the low $R_{s h}$. A similar trend for the CdS/CdTe cells was observed in the $J-V$ curves.

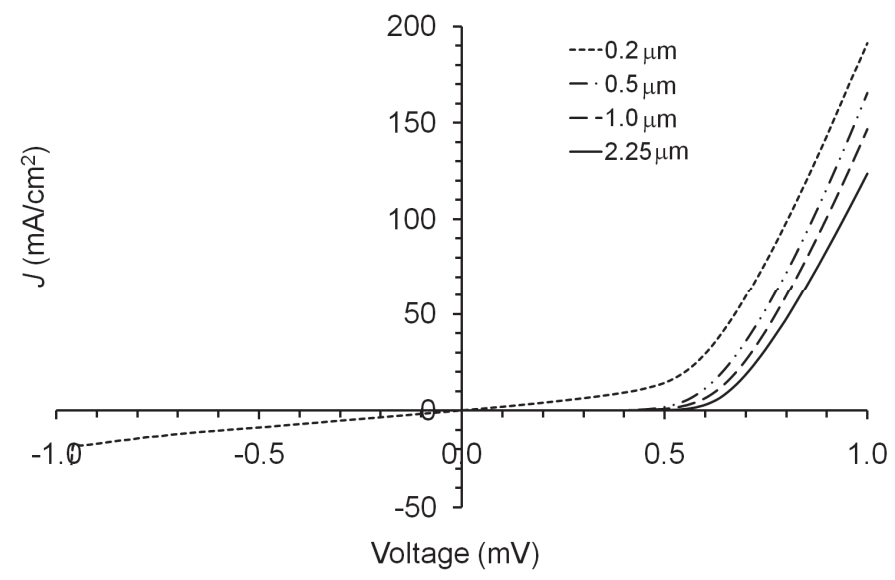

Fig. 1. Dark J-V curves for $\mathrm{Cd}_{(1-\mathrm{x})} \mathrm{Zn}_{(\mathrm{x})} \mathrm{S} / \mathrm{CdTe}$ cells with CdTe absorber thicknesses ranging from 2.25 to $0.2 \mu \mathrm{m}$.

The decrease in cell efficiency as the CdTe layer thickness was reduced is illustrated in Fig. 2 with a gradual change from the baseline device down to the devices with $0.5 \mu \mathrm{m} \mathrm{CdTe}$ absorber for both $\mathrm{Cd}_{(1-\mathrm{x})} \mathrm{Zn}_{(\mathrm{x})} \mathrm{S} / \mathrm{CdTe}$ and $\mathrm{CdS} / \mathrm{CdTe}$ cell structures, with a more rapid fall when the absorber was $0.2 \mu \mathrm{m}$ in thickness. The loss in cell efficiency is greater than that expected from just optical absorption limited performance where $8 \%$ efficiency was predicted for a $0.5 \mu \mathrm{m}$ thick CdTe cell [3]. This is explained by electrical degradation in performance due to the presence of micro-shorts in the ultrathin cells. Degradation of $\mathrm{Cd}_{(1-\mathrm{x})} \mathrm{Zn}_{(\mathrm{x})} \mathrm{S} / \mathrm{CdTe}$ cell performance as the CdTe thickness was reduced follows a similar pattern to that observed by Jones et al. [3] for CdS/CdTe solar cell devices. 


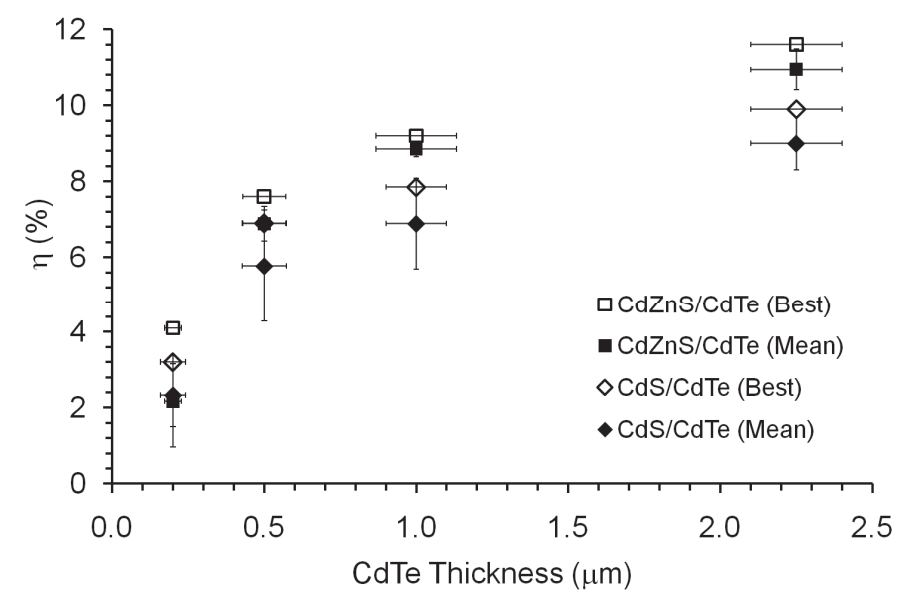

Fig. 2. Mean and best efficiencies with standard deviation error for $C d_{(1-x)} Z n_{(x)} S / C d T e$ and CdS/CdTe cell for CdTe absorber thicknesses ranging from 2.25 to $0.2 \mu \mathrm{m}$.

\subsection{Spectral response}

External quantum efficiency (EQE) of the $\mathrm{Cd}_{(1-x)} \mathrm{Zn}_{(\mathrm{x})} \mathrm{S} / \mathrm{CdTe} \mathrm{PV}$ cells was observed (Fig. 3 ) to decrease with CdTe thickness over the main photon absorption range. Previous reports $[1,10]$ however, discussed a large loss at longer wavelengths due to decreasing photon absorption for increasing wavelength up to the band edge. This expected optical absorption related EQE behaviour has not been observed here. The uniform reduction in EQE over the red and near infrared wavelengths (Figs. 3 and 4 ) as the CdTe absorber thickness was reduced is consistent with the presence of micro-shorts that increase in density with thinner CdTe.

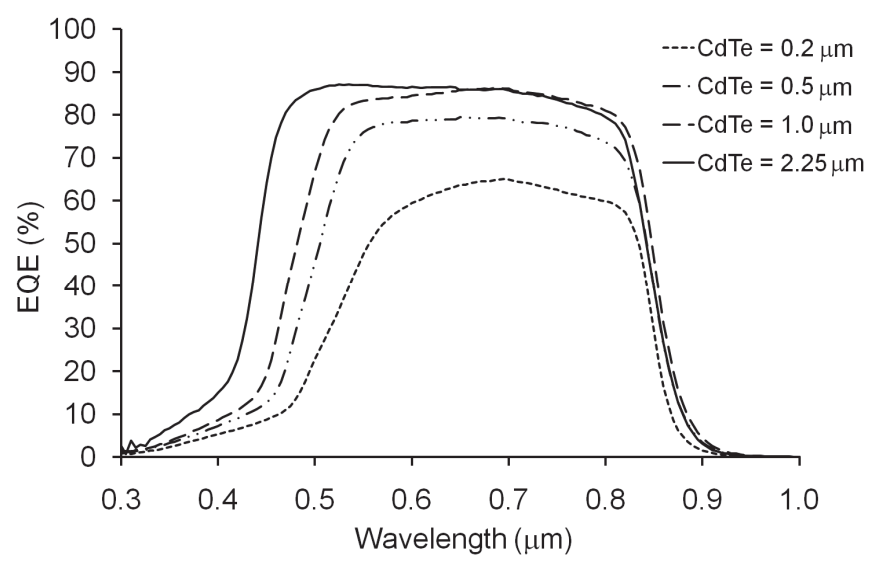

Fig. 3. Spectral response in terms of EQE for $C d_{(1-x)} Z n_{(x)} S / C d T e$ cells as function of CdTe absorber thickness between 0.2 and $2.25 \mu \mathrm{m}$.

The EQE data in Fig. 3 also exhibits a clear red-shift in the short wavelength absorption edge (due to the window layer) as the CdTe absorber layer thickness was reduced. This result is found to be reproducible both among different cells on the same sample and specimens produced from different growth runs. Interestingly, however, the EQE curves of the equivalent CdS/CdTe cells (Fig. 4) did not show any shift in window layer absorption edge with absorber thickness. However, the EQE curves for these cells showed the same behaviour in the red and infrared for decreasing absorber thickness as for the $\mathrm{Cd}_{(1-\mathrm{x})} \mathrm{Zn}_{(\mathrm{x})} \mathrm{S} / \mathrm{CdTe}$ cells. 


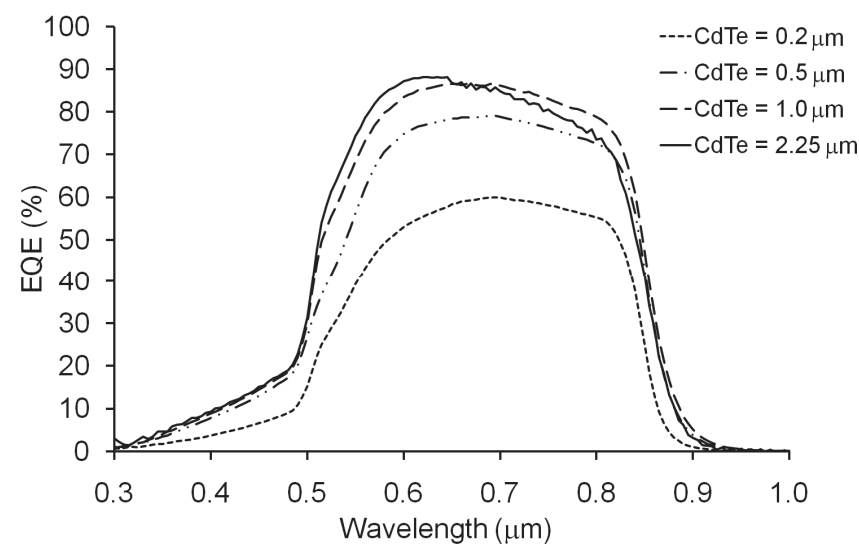

Fig. 4. Spectral response spectra showing EQE curves for CdS/CdTe cells with CdTe absorber thicknesses ranging from $2.25 \mu \mathrm{m}$ to $0.2 \mu \mathrm{m}$.

During $\mathrm{CdCl}_{2}$ treatment and post-anneal, it is known that an intermixed alloy layer of $\mathrm{CdS}_{\mathrm{x}} \mathrm{Te}_{1-\mathrm{x}}$ forms $[14,15]$ at the interface, with Te diffusing into the CdS layer and S diffusing into the CdTe layer, and has been reported to occur more quickly in cells with thin CdTe [10]. If the level of intermixing varied for cells with different CdTe thicknesses, EQE of both CdS/CdTe and $\mathrm{Cd}_{(1-x)} \mathrm{Zn}_{(\mathrm{x})} \mathrm{S} / \mathrm{CdTe}$ cells would show an increase in EQE in the blue region due to the effective decrease in window layer thickness. This is not observed for either cell structure (Figs. 3 and 4) ruling out significant intermixing between the $\mathrm{Cd}_{(1-x)} \mathrm{Zn} \mathrm{n}_{(\mathrm{x})} \mathrm{S}$ and CdTe layer interface as the cause of shift in window layer absorption edge towards longer wavelengths.

Therefore, based on the evidence, the shift in EQE short wavelength edge for the $\mathrm{Cd}_{(1-x)} Z \mathrm{n}_{(\mathrm{x})} \mathrm{S} / \mathrm{CdTe}$ cells is more likely due to diffusion of the $\mathrm{Zn}$ out of the window layer at the junction interface, leading to the observed red-shift. This will result in the overall window layer having less $\mathrm{Zn}$ content, giving the shift of the absorption edge towards that expected for CdS (comparing Figs. 3 and 4). The mechanism for $\mathrm{Zn}$ diffusion from the window layer maybe related to the $\mathrm{CdCl}_{2}$ anneal step. As mentioned in section 2.2, $\mathrm{CdCl}_{2}$ deposition time was reduced by half for all ultra-thin devices from the parameters used for the baseline cells (irrespective of the absorber layer thickness), keeping the thermal anneal the same at $10 \mathrm{~min}$. As the CdTe absorber thickness is reduced, the extent of $\mathrm{Zn}$ leaching out of the window layer is increasing at the same time as the $\mathrm{Cl}$ concentration is increasing. Additionally, over-treatment with $\mathrm{CdCl}_{2}$ has been reported by Burgelman et al. [16] to introduce a high density of deep acceptor states having a profound effect on measured spectral response. By keeping a constant thickness and anneal time for the $\mathrm{CdCl}_{2}$ treatment, the ultra-thin $\mathrm{CdTe}$ layers would have had an increasing concentration of $\mathrm{Cl}$ as the possible cause for $\mathrm{Zn}$ leaching. To summarise, the EQE curves for the ultra-thin cells support the following traits:

i. The decrease in EQE in the red and near infrared was uniform across this wavelength range and did not follow the expected loss of absorption with wavelength;

ii. The additional effects of micro-shorts caused by an increased number of pin-holes, as the CdTe absorber thickness was reduced, resulted in performance of the ultra-thin cells being lower than the optically limited performance;

iii. Window layer thickness did not vary as the CdTe absorber layer thickness was reduced;

iv. The clear red-shift of the window layer absorption edge for $\mathrm{Cd}_{(1-x)} \mathrm{Zn}_{(\mathrm{x})} \mathrm{S} / \mathrm{CdTe}$ cells with decreasing $\mathrm{CdTe}$ absorber layer thickness has been attributed to $\mathrm{CdCl}_{2}$ treatment leaching out $\mathrm{Zn}$ from the $\mathrm{Cd}_{(1-\mathrm{x})} \mathrm{Zn} \mathrm{n}_{(\mathrm{x})} \mathrm{S}$ window layer.

\subsection{Investigation of $\mathrm{CdCl}_{2}$ treatment}

In order to investigate the $\mathrm{Zn}$ leaching effect, $\mathrm{CdCl}_{2}$ deposition thickness and anneal time were varied for the treatment of $\left.\mathrm{Cd}_{(1-x)}\right) \mathrm{n}_{(\mathrm{x})} \mathrm{S} / \mathrm{CdS}$ cells, with $\mathrm{CdTe}$ absorber thickness of $0.5 \mu \mathrm{m}$; these cells showed good back contact quality without roll-over in the $J-V$ curves as well as having a clearly identifiable shift in the front absorption edge (see Figs. 1 and 3). Spectral response of the $\mathrm{Cd}_{(1-}$ ${ }_{x)} \mathrm{Zn}_{(\mathrm{x})} \mathrm{S} / \mathrm{CdS}$ cells with $0.5 \mu \mathrm{m}$ thick CdTe are shown in Fig. 5 with the details of the different $\mathrm{CdCl}_{2}$ 
deposition and anneal parameters for the different devices, labelled Sample A - D, displayed in Table 3 (Sample A being the $\mathrm{Cd}_{(1-x)} Z \mathrm{n}_{(\mathrm{x})} \mathrm{S} / \mathrm{CdTe}$ device from the results discussed earlier in this paper). A device without any post-growth treatment (labelled Control) was also produced to compare EQE with no $\mathrm{Cl}$ at the $\left.\mathrm{Cd}_{(1-\mathrm{x})}\right) \mathrm{n}_{(\mathrm{x})} \mathrm{S} / \mathrm{CdTe}$ interface.

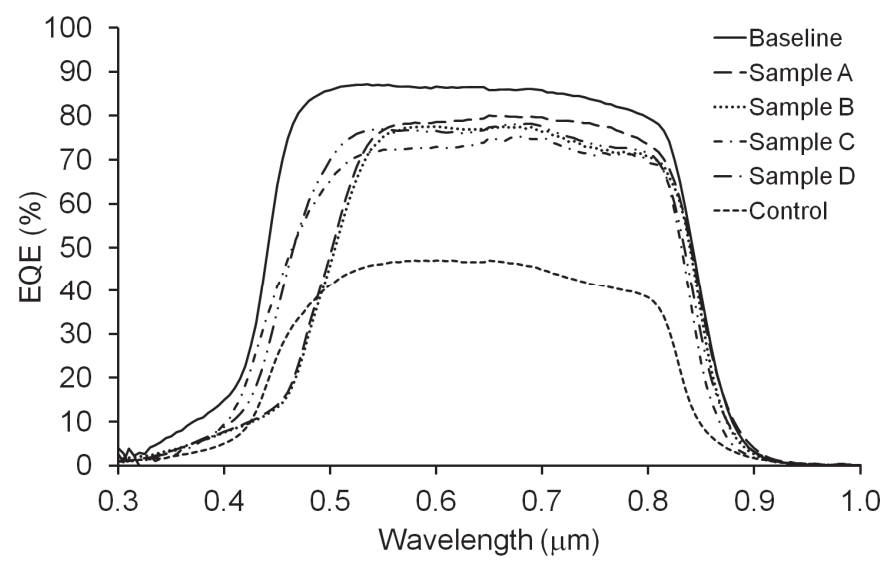

Fig. 5. Spectral response (EQE) for $C d_{(1-x)} Z n_{(x)} S / C d T e$ cells with $0.5 \mu m$ CdTe absorber and different post-growth $\mathrm{CdCl}_{2}$ and anneal treatment, with Control cell having no post-growth treatment and baseline cell with standard post-growth treatment.

Table 3: Mean results with standard deviation error from J-V measurements for $C d_{(1-x)} Z n_{(x)} S / C d T e$ cells with $0.5 \mu \mathrm{m}$ thick CdTe absorber with different post-growth $\mathrm{CdCl}_{2}$ and anneal treatment.

\begin{tabular}{cccccc}
\hline Sample & $\begin{array}{c}\mathbf{C d C l}_{2}(\mathbf{s}) \\
\text { IAnneal (s) }\end{array}$ & Eff (\%) & $\mathbf{J}_{\mathbf{s c}}\left(\mathrm{mA} / \mathbf{c m}^{2}\right)$ & $\mathbf{V}_{\text {oc }}(\mathbf{m V})$ & $\mathbf{F F}(\%)$ \\
\hline $\mathrm{A}$ & $179 / 600$ & $6.9+/-0.5$ & $19.4+/-0.5$ & $579+/-10$ & $61.5+/-3.5$ \\
$\mathrm{~B}$ & $179 / 120$ & $4.3+/-2.1$ & $18.8+/-0.4$ & $467+/-126$ & $46.3+/-14.2$ \\
$\mathrm{C}$ & $80 / 600$ & $6.2+/-0.5$ & $18.3+/-0.5$ & $548+/-17$ & $60.1+/-4.7$ \\
$\mathrm{D}$ & $80 / 120$ & $6.8+/-0.2$ & $19.6+/-0.3$ & $545+/-11$ & $63.4+/-1.1$ \\
Control & zero / zero & $2.6+/-0.5$ & $11.1+/-0.7$ & $483+/-7$ & $47.9+/-4.2$ \\
\hline
\end{tabular}

The EQE curves in Fig. 5 show that there was no change in window layer absorption edge for Sample B (compared to Sample A), which only had a reduction in anneal time from 10 to $2 \mathrm{~min}$. For Sample $\mathrm{C}$, the $\mathrm{CdCl}_{2}$ deposition time (and hence thickness) was reduced in proportion to the CdTe thickness with regards to the baseline sample parameters, but the anneal time was held at 10 min. Fig. 5 clearly shows that the reduction of $\mathrm{CdCl}_{2}$ deposition time (i.e. $\mathrm{CdCl}_{2}$ thickness) resulted in a reduction in the red-shift observed for Sample $\mathrm{C}$. The window layer absorption edge is comparable to that of the 'Control' sample demonstrating that the reduced $\mathrm{CdCl}_{2}$ deposition has diminished the effect of $\mathrm{Cl}$ leaching out the $\mathrm{Zn}$ from the $\mathrm{Cd}_{(1-\mathrm{x})} \mathrm{Zn}_{(\mathrm{x})}$ S layer.

Sample D represents post-growth treatment using both the reduction in $\mathrm{CdCl}_{2}$ deposition time and duration of anneal. Table 3 shows that $J-V$ results for Samples $A$ and $D$ are comparable, despite the gain of blue photon conversion in Sample $D$, which is compensated by the reduced photo-current generated in the red region. The shorter anneal time has improved $J-V$ parameters relative to Sample $\mathrm{C}$, but there is no clear trend that can be obtained from these results. Both the amount of $\mathrm{CdCl}_{2}$ deposited and the $\mathrm{Cl}$ diffusion time during anneal are having an effect on spectral response of the cells but further optimisation will be required. The results do, however, show clearly that the parameters of the post-growth treatment process have had a major effect on the cell performances of the ultra-thin $\mathrm{Cd}_{(1-x)} \mathrm{Zn}_{(\mathrm{x})} \mathrm{S} / \mathrm{CdTe}$ cells, explaining why the window absorption edge shifts towards longer wavelengths as the $\mathrm{CdTe}$ absorber thickness reduces.

SIMS was carried out (Fig. 6) on Sample A and Sample C to assess differences in Zn content between the CdTe and $\mathrm{Cd}_{(1-x)} Z \mathrm{n}_{(\mathrm{x})} \mathrm{S}$ layers for the two samples as a ratio of intensity (counts/second) in each layer. 


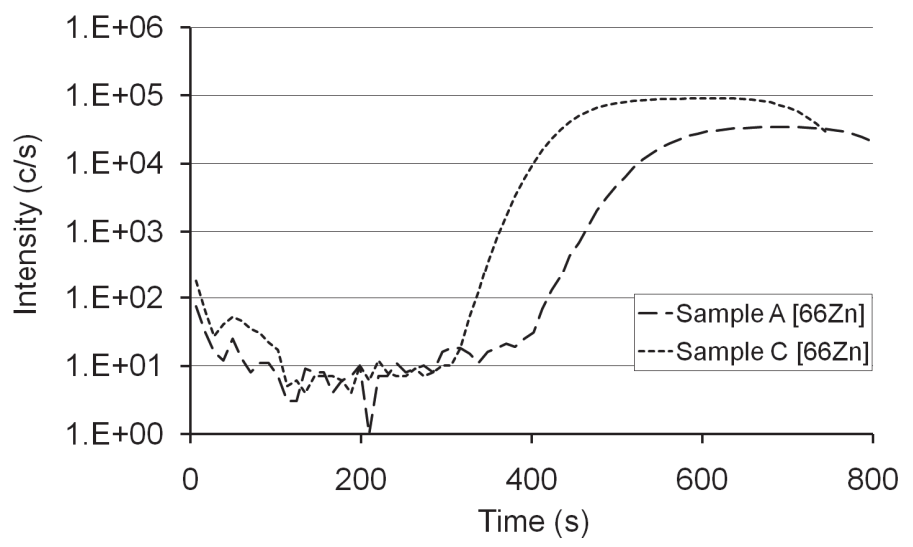

Fig. 6: SIMS traces of Samples A and C showing Zn depth profiles through the device structure.

The $\mathrm{Zn}$ secondary ion count for Sample $\mathrm{A}$ as a ratio in the $\mathrm{Cd}_{(1-\mathrm{x})} \mathrm{Zn_{( \textrm {x } ) }} \mathrm{S}$ and $\mathrm{CdTe}$ layers was calculated to be 3583:1, whereas this ratio was found to be 11352:1 for Sample $C$, thus demonstrating that the $\mathrm{Zn}$ content had reduced by more than threefold in the window layer for Sample A relative to Sample $\mathrm{C}$ due to greater $\mathrm{CdCl}_{2}$ treatment. Further investigation of the post-growth treatment is required in order to improve ultra-thin cell performances, which will be an ongoing study for future work.

\section{Conclusions}

Solar cell performance improved with CdTe absorber thicknesses down to $0.5 \mu \mathrm{m}$ when using the wider band gap $\mathrm{Cd}_{(1-\mathrm{x})} \mathrm{Zn}_{(\mathrm{x})} \mathrm{S}$ window layer in comparison to equivalent $\mathrm{CdS} / \mathrm{CdTe}$ structures due to better response in the blue region. All $J-V$ parameters, with exception of $R_{s}$, degraded with $C d T e$ thickness, being more pronounced than if cell performance was only optically limited, resulting in the loss of photo-current generation becoming more and more significant as CdTe became thinner. In particular, $R_{s h}$ became very low for the thinnest cells due to greater lateral non-uniformity across the device creating a larger number of pin-holes resulting in increased micro-shorts. Ultra-thin cells using the $\mathrm{Cd}_{(1-x)} \mathrm{Zn}_{(\mathrm{x})} \mathrm{S} / \mathrm{CdTe}$ structure lost the benefit of improved blue response due to leaching of $\mathrm{Zn}$ from the window layer associated with the $\mathrm{CdCl}_{2}$ treatment process. Reduction of the $\mathrm{CdCl}_{2}$ layer thickness has been shown to recover blue-response in the ultra-thin $C d_{(1-x)} Z_{(x)} S / C d T e$ cells, which should result in higher conversion efficiencies for the $\mathrm{Cd}_{(1-\mathrm{x})} \mathrm{Zn} \mathrm{n}_{(\mathrm{x})} \mathrm{S} / \mathrm{CdTe}$ PV cells once optimised.

\section{Acknowledgements}

The authors would like to thank the engineering and physical science research council (EPSRC) for funding the PV21 Supergen consortium that supports this work, SAFC Hitech for supplying the organometallic precursors, Loughborough Surface Analysis for the SIMS measurements and Steve Jones and Fraser Hogg at CSER for their technical support.

\section{References}

1 N. Amin, K. Sopian, M. Konagi, Numerical modeling of CdS/CdTe and CdS/CdTe/ZnTe solar cells as a function of CdTe thickness, Sol. Energy Mater. Sol. Cells, 91 (2007) 1202-1208.

2 S.J.C. Irvine, V. Barrioz, A. Stafford, K. Durose, Materials issues in very thin CdTe for photovoltaics, Thin Solid Films, 480-481 (2005) 76-81.

3 E.W. Jones, V. Barrioz, S.J.C. Irvine, D. Lamb, Towards ultra-thin CdTe solar cells using MOCVD, Thin Solid Films, 517, 2009, 2226-2230.

4 T. L. Chu, S. S. Chu, J. Britt, C. Ferekides, C. Q. Wu, Cadmium zinc sulfide films and heterojunctions, J. Appl. Phys., 70 (1991) 2688-2693. 
5 S.J.C. Irvine, V. Barrioz, D. Lamb, E.W. Jones, R.L. Rowlands-Jones, MOCVD of thin film photovoltaic solar cells - Next generation production technology?, J. Cryst. Growth, 310 (2008) 5198-5203.

6 V. Barrioz, Y.Y. Proskuryakov, E.W. Jones, J.D. Major, S.J.C. Irvine, K. Durose, D.A. Lamb, Highly arsenic doped CdTe layers for the back contacts of CdTe solar cells, Mater. Res. Soc. Symp. Proc. (2007) 1012, Y12-08.

7 V. Barrioz, S.J.C.Irvine, E.W. Jones, R.L. Rowlands, D.A. Lamb, In situ deposition of cadmium chloride films using MOCVD for CdTe solar cells, Thin Solid Films, 515 (2007) 5808-5813.

8 S.J.C. Irvine, D.A. Lamb, V. Barrioz, A.J. Clayton, W.S.M. Brooks, S. Rugen-Hankey, G. Kartopu, The role of transparent conducting oxides in metal organic chemical vapour depostion of CdTe/CdS photovoltaic solar cells, Thin Solid Films, 520 (2011) 1167-1174.

9 V. Plotnikov, X. Liu, N. Paudel, D. Kwon, K.A. Wieland, A.D. Compaan, Thin-film CdTe cells: Reducing the CdTe, Thin Solid Films 519 (2011) 7134-7137.

10 A. Gupta, V. Parikh, A.D. Compaan, High efficiency ultra-thin sputtered CdTe solar cells, Sol. Energy Mater. Sol. Cells, 90 (2006) 2263-2271.

11 M. Burgelman, J. Verschraegen, S. Degrave, P. Nollet, Analysis of CdTe solar cells in relation to materials issues, Thin Solid Films, 480-481 (2005) 392-398.

12 W.S.M. Brooks, S.J.C. Irvine, V. Barrioz, High-resolution laser beam induced current measurements on $\mathrm{Cd}_{0.9} \mathrm{Zn}_{0.1} \mathrm{~S} / \mathrm{CdTe}$ solar cells, Energy Procedia 10 (2011) 232-237.

13 W.S.M. Brooks, S.J.C. Irvine, V. Barrioz, A.J. Clayton, Laser beam induced current measurements of $\mathrm{Cd}_{1-x} \mathrm{Zn}_{\mathrm{x}} \mathrm{S} / \mathrm{CdTe}$ solar cells, Sol. Energy Mater. Sol. Cells (2012) submitted.

14 W. Jaegermann, A. Klein, J. Fritsche, D. Kraft, B. Späth, Interfaces in CdTe solar cells: From idealised concepts to technology, Mater. Res. Soc. Symp. Proc., 865 (2005) F6.1.1-1.13.

15 D. Albin, Y. Yan, M.M. Al-Jassim, The effect of oxygen on interface microstructure evolution in CdS/CdTe solar cells, Prog. Photovoltaics Res. Appl., 10 (2002) 309-322.

16 M. Burgelman, P. Nollet, S. Degrave, Modelling polycrystalline semiconductor solar cells, Thin Solid Films, 361-362 (2000) 527-532. 